\title{
Analysis of Energy Efficiency Policy on the Heat Transfers Process
}

\author{
Indriyani Indriyani ${ }^{1}$, Henni Kusumastuti ${ }^{2}$, Nur aeni Nur aeni ${ }^{3}$ \\ \{indriyani@saburai.ac.id ${ }^{1}$, henni_ksa65@saburai.ac.id ${ }^{2}$, nuraeni@saburai.ac.id ${ }^{3}$ \}
}

\begin{abstract}
${ }^{1}$ Mechanical Engineering Study Program of Engineering Faculty, University of Sang Bumi Ruwa Jurai, Jl. Imam Bonjol Street No. 468 Langkapura Bandar Lampung Post Code 35154, Indonesia State Administration Study Program of Social and Politics Faculty, University of Sang Bumi Ruwa ${ }^{2}$ Jurai, Jl. Imam Bonjol Street No. 468 Langkapura Bandar Lampung Post Code 35154, Indonesia ${ }^{3}$ Management Study Program of Economic Faculty, University of Sang Bumi Ruwa Jurai, Jl. Imam Bonjol Street No. 468 Langkapura Bandar Lampung Post Code 35154, Indonesia
\end{abstract}

\begin{abstract}
Energy efficiency policy analysis in the heat transfer's process can be done in three ways, namely by means of emission / radiation, by means of flow / convection, and by means of propagation or conduction. The surface of the water in the boiler is printed at least $100 \mathrm{~mm}$ above the wall of the boiler, for the boiler to be fixed on land. As for the steam boiler carried, the minimum distance between the lowest water level and the highest part of the boiler that is still touched on by fire / smoke gas is $250 \mathrm{~mm}$. The heat needed from $290 \mathrm{C}$ to $900 \mathrm{C}$ to heat $14 \mathrm{~kg}$ of water is 3,584 kilo joules. The amount of heat needed in the heat transfer available through the heat transfer process with a capacity of 2 tons per hour is 5,862,000 kilo joules per hour.
\end{abstract}

Keywords: policy analysis, energy efficiency, process, heat transfer

\section{Introduction}

Energy is one of the important problems in every country, both developing and developed countries. Today's progress is accompanied by very rapid technological advances in all fields, one of which is progress in the industrial and engineering machineries that aim to help and facilitate humans in doing work. Indonesia is a developing country, and many construction workshops and companies use boilers (boilers / energy conversion). To help the development / smoothness of work, and meet the needs of power / power which is greatly increased is to convert the energy contained in conventional fuel into power needed in development. Utilization of conventional fuels can use piston engines or gas turbines, for small or medium scale. Steam generators (steam generators) are usually used in power installations.[1]

Power plants that use fossil fuels and nuclear fuels. The most up-to-date steam generators produce high-pressure advanced hot steam (2400 to 3500 psia, 165 to 240 bar). Steam generators are a complex combination of economators, advanced hot boilers, master heaters, and air preheaters.

Boilers (boiler) are part of a steam generator where saturated liquid is converted to saturated steam. The function of a boiler is not easy to distinguish from an economist, 
sometimes it is used in the literature for a whole steam generator. For large-scale power conversion from conventional fuel to the required power, a combination of steam boiler and steam tubing can be used to convert energy. Because basically found a certain amount of energy that can be used for other purposes. Heat transfer (heat transfer) is the science of predicting the transfer of energy in the form of heat that occurs due to temperature differences between objects / materials, but it can also predict the rate of transfer under certain conditions.

\section{Literature Review}

In planning and perator-installation of power is usually more efficient as a measure of economic power-installation because it affects the cost of investment, fuel costs, and operating costs. The rate of heat is the amount of heat added usually in Btu, to produce a unit of work, usually in kilowatts $(\mathrm{kWh})$. So the unit of caloric rate is Btu / hour. HR is inversely proportional to efficiency, meaning that the lower the higher.[2]

Thermal efficiency is the ratio between net work and heat added to the cycle or powerinstallation. Gross efficiency is the efficiency calculated on the basis of the gross work or gross power of the turbine generator. Gross MW work or power is generated before some of the power is taken to run the power installation, that is, to run pumps, compressors, fuel handling equipment.

Laboratory tests are used to assess the nature and quality of the fuel. So to do the combustion needed three elements, namely: Fuel • Oxygen - Temperature to start combustion - Heat (heat) arising from burning the fuel is called the result of combustion or heating value of the fuel (Heating Value). Heating Value The heating value is the amount of heat energy obtained from burning $1 \mathrm{~kg}$ of fuel. The heating value is divided into: 1 . High heating value or High Heating Value (HHV) is the amount of heat produced in the combustion process of $1 \mathrm{~kg}$ of fuel, without any water content in the fuel. 2. Low heating value or Low Heating Value (LHV) is the amount of heat produced in the combustion process of $1 \mathrm{~kg}$ of fuel and some of it is used so that the water content in the fuel will be used up.[3]

\section{Research Methodology}

\subsection{Type of Research}

Research by the author is to survey observations (review / view) and at the same time examine and analyze directly the part of heat transfer in the boiler.

\subsection{Research Place and Time}

The research was conducted in Bandar Lampung, located at Jalan Yos Sudarso Bandar Lampung. The time of the study was carried out on 2 March 2019 - 31 July 2019.

\section{Research Results and Discussion}

If the amount of heat needed by $14 \mathrm{~kg}$ of water from a temperature of $290 \mathrm{C}$ to be heated to $900 \mathrm{C}$, then using table 3 . Noted for heating $1 \mathrm{~kg}$ of water from $00 \mathrm{C}$ to $290 \mathrm{C}$ required $\mathrm{W} 290 \mathrm{C}$ or $121 \mathrm{KJ} / \mathrm{kg}$, while for heating $1 \mathrm{~kg}$ of water from $00 \mathrm{C}$ to $900 \mathrm{C}$ requires as much heat Q: $\mathrm{W}=(\mathrm{W} 900 \mathrm{C}-\mathrm{W} 290 \mathrm{C}) \mathrm{KJ} / \mathrm{kg}=(377-121) \mathrm{KJ} / \mathrm{kg}$. So that $14 \mathrm{~kg}$ of water that is heated from $290 \mathrm{C}$ to $900 \mathrm{C}$ will heat as much as $\mathrm{Q}=14 \mathrm{~kg} \times(377-121) \mathrm{KJ} / \mathrm{kg}=3,584$ 
kilojoules.

By using the formula $\mathrm{Q}=\mathrm{G}$ x enthalpy, so $\mathrm{G}=$ weight of water in kilograms enthalpy = final enthalpy - initial enthalpy. W900C - W290C. The enthalpy of water at temperature T0C is $\mathrm{Wt}$, or the medal enthalpy of water is $\mathrm{Wd}$, the full enthalpy of steam ie $\mathrm{i}$ "is no longer calculated based on specific heat, either water type heat or steam type heat (Cp) and evaporation of $\mathrm{r}$; because it turns out that the specific heat or evaporation heat is not constant for various pressures and temperatures. When the pressure in the vessel is changed to P3 N / $\mathrm{m} 2$ by changing the ballast $\mathrm{G} 2$ to $\mathrm{G} 3$ above the piston shear free $\mathrm{P}$, for any given pressure of the Wd (enthalpy of boiling water) value.

Efficiency is a barometer of a machine's performance. Understanding the efficiency of a boiler engine, which is the value of the ability level of boiler performance obtained from the comparison between the output energy (output) with the incoming energy (input). This methodology is often referred to as the direct / input - output method because the efficiency value is obtained from the division between output / output (steam) with heat input / input (fuel).

Comparison of the average value of boiler efficiency in the calculation of efficiency can be seen the average value of the efficiency of the boiler at the time of commissioning of $88.51 \%$ and the average value of boiler efficiency of operational conditions by $79.32 \%$ a decrease in boiler efficiency by $9.19 \%$. One of the factors analysis of the decline in boiler efficiency is caused by the cleanliness of the pipe surface on the boiler, very influential on the process of heat transfer / heat transfer, because if there is dirt or crust on the boiler pipe and deposition (fouling), will result in the process of heat transfer / heat transfer will be reduced so that the rate of heat transfer will decrease, and will also affect the high value of the exhaust gas temperature which affects the amount of other heat losses in the boiler.[4] Energy requirements in boiler furnaces are calculated based on the difference in enthalpy of water in the boiler inlet and steam enthalpy of water in the boiler outlet. From the results of the analysis of combustion of biomass fuels, it can be seen: Energy surplus obtained from burning shells and fibers, on a basis of 20 hours per day when operational; in the amount of 20 hours per day x $15060.88 \mathrm{~kg} /$ day $=301.2176 \mathrm{MT} /$ day. This shows that there is an excess in the supply of fuel into the combustion chamber, although in the production process it is often neglected due to operational constraints such as the appropriate supply of fuel such as having an M.C content and a constant heat value.[4]

Large energy losses are also due to exhaust gas coming out of the chimney, which is $8.99 \%$ for Yoshimine H-2700 Steam Boilers and 9.46\% for Yoshimine H-3500 Steam Boilers, this can actually be avoided for example by reducing the air excess, reduced to a minimum value but still in sufficient condition, the temperature of the chimney gas is reduced by optimizing maintenance in the combustion chamber. Heat loss due to incomplete combustion is around 2.5\% for Yoshimine H-2700 Steam Boiler and 2.85\% for Yoshimine H-3500 Steam Boiler, Incomplete combustion can actually be avoided for example by improving the distribution of sugarcane bagasse in the kitchen so that air and material mixing burn sugarcane bagasse to be more perfect resulting in combustion to be perfect.[5]

In modern societies buildings largely contribute to the energy demand and account in some countries for up to $45 \%$ of the primary energy consumption. Detailed consumption data can be used to offer advanced services and provide new business is opportunities to all participants in the energy supply chain. In recent years, the intensified research effort by the scientific community and companies from the energy sector has led to an improved estimation of the building energy consumption. This paper proposes a tool that combines on one hand architectural characteristics and, on the other, user interactions with a building to precisely 
estimate its energy consumption and supply costs. The tool also determines the sensitivity of the energy consumption and the related costs for any variations applied in the building configuration or in the energy tariffs. The identification of critical parameters allows building managers to adopt appropriate measures to improve energy efficiency of the considered building. For the demonstration and validation of the proposed approach the developed tool is then applied to a case of an office building located in Madrid (Spain).It is explained in detail how the estimates of the building energy consumption and the costs were calculated and the sensitivity analysis performed.[6]

\section{Conclusions And Suggestions}

\subsection{Conclusions}

Based on the results of the research that has been done, several conclusions can be drawn, namely:

1. The process of heat transfer in a steam boiler through 3 ways, by means of transmission / traditional, by means of flow / convection, and by means of propagation or conduction. While the heat transfer process in the boiler in the Hotel Sahid Bandar Lampung is through the beam / tradition.

2. The heat needed from $290 \mathrm{C}$ to $900 \mathrm{C}$ to heat $14 \mathrm{~kg}$ of water is 3,584 Kilojoules.

3. The amount of heat needed in the steam boiler in Bandar Lampung through the process of heat transfer with a capacity of 2 tons per hour is 5,862,000 Kilojoules per hour.

\subsection{Suggestions}

1. The quality of the water before processing it in the steam boiler at the Sahid Hotel in Bandar Lampung should be of clean quality, in the sense that it is free of odor, odorless, colorless and must be sterile (held in a laboratory test first).

2. Steam boiler maintenance should be carried out periodically, both on water pipes and on burners and removing crust so that the life of the boiler can last a long time.

\section{Reference}

[1] T. P. R. E. R. S. Bambang Sucahyo, Dwi Lukman H, Rohmadi Ridlo, "Study of Technology Utilization of Biomass Pome (Palm Oil Mill Effluent) to Boilers (Study of the Technology of Utilizing Biogas From Palm Oil Effluent Mill (Pome) to Boilers," MIPI, vol. Vol.13, p. 43.

[2] Andrizal, "Steam Boilers, Mechanical Engineering Study Program," Fac. Eng. Univ. Saburai, Bandar Lampung, 2015.

[3] F. B. A. S. S. Khaidir Maulana, Lukman, "Efficiency Analysis of Fiber Tube and Water Shell Boilers in Palm Oil Mill Capacity of 60 Tons Tbs / Hour by Using Chemicalogic Steamtab Companion," Chemica.

[4] A. M. I. Muzaki, "Boiler Efficiency Analysis with Input-Output Method at PT Japfa Comfeed Tbk Unit Banjarmasin," SJME Kinemat., vol. 4, no. 1, p. 37.

[5] H. Hendaryati, "Thermal Efficiency Analysis on Steam Boilers in Malang Kebon Agung Sugar Factory," J. GAMMA, vol. 8, p. 148. 
[6] M. P. R. A. John k. Gruber, "Estimation and analysis of building energy demand and supply costs, Electrical Systems Unit,” IMDEA Energy Inst. 28935 Most. Spain, no. Energy Procedia 83, p. 23. 
